\title{
THE EFFECT OF A PHYSICAL TRAINING PROGRAMME ON FLEXIBILITY OF UPPER BODY AND TRUNK IN VISUALLY IMPAIRED AND DEAF-BLIND PERSONS Airi Surakka* Tero Kivelä**
}

\author{
* Department of Ophthalmology, Helsinki University Central \\ Hospital, Finland \\ ** Department of Ophthalmology, Helsinki University Central \\ Hospital, Finland
}

\begin{abstract}
Optimal twist of the trunk, shoulder rotation and reciprocal arm swings are necessary for good balance and gait. The purpose of this study was to examine the effect of a multidimensional physical training programme on flexibility of the upper body and trunk in visually impaired and deaf-blind persons. Participants were assigned randomly to the experimental and the control group. Fifteen participants (12 visually impaired and three deaf-blind, mean age 55 years, SD 9.0) completed the 5-6-week long physical training programme (three 60-minute sessions per week). The control group consisted of 14 participants (nine visually impaired and five deaf-blind, mean age 57 years, SD 7.2). Two flexibility tests from the Health-Related Fitness Test battery of the UKK Institute were used to assess the results. The experimental group showed statistically significant improvement in flexibility of the trunk (mean of side-bending to the left and right, $\mathrm{p}=.0068$ Wilcoxon signed rank test). In the experimental group a pre-test showed unrestricted flexibility of the upper body in seven participants. In a post-test four participants showed improved flexibility. The test-retest of the control group showed good reliability of these two tests. The Fligner \& Policello rank test did not show any statistical difference between the participants with and without regular physical activity $(\mathrm{p}=.49)$
\end{abstract}

KEYWORDS: physical training, flexibility measurement methods, visual impairment, deaf-blind

\section{INTRODUCTION}

Vision plays a major role in both the maintenance of balance and its recovery. Visual impairment can affect the equilibrium of proprioceptive systems, resulting in problems with balance, posture, coordination, tension of the neck and shoulder muscles, and loss of spinal rotation and reciprocal arm swing (Rosen, 1997). Dynamic balance results from the integration of several sensory and motor functions, including vestibular, proprioceptive, and visual inputs (Woollacott, Debu, \& Mowatt, 1987). Individuals with vision loss have decreased postural stability. Therefore they are unable to compensate for restricted visual input to maintain postural stability (Ray, Horvat, Croce, Mason, \& Wolf, 2008). Having a dual sensory impairment (i.e. hearing and visual) further aggravates balance as each affects balance and posture (Howe \& Oldham, 2001). Postural control and balance involve controlling the position of the body in space for stability and orientation (Shumway-Cook, \& Woollacott, 2001). Visually impaired and deaf-blind persons need these basic motor skills in straight-line walking and for detecting veering (Welsh, 1997). Poor balance results in problems with straight walking and control of turns, thus making independent navigation difficult.

Optimally coordinated functioning of the muscles and the entire kinetic chain is important for balance and effective walking. Optimal twist of the trunk, shoulder rotation and reciprocal arm swings are necessary for good balance and gait (Whittle, 2007). In optimal posture and balance, body segments are aligned one on top of the other, so that the centre of gravity of each segment is directly 
above the centre of gravity of the one below (Rosen, 1997). Body segments are sequentially activated to perform functional or athletic tasks, and the activation sequence is known as the kinetic chain (Kibler, 1998; Kibler, McMullen, \& Uhi, 2001). The upper limb is part of the kinetic chain linked to the other parts of the body (Sparkes, 2005).

Functioning of the upper limb relies on the optimum functioning of all the neurophysiologic systems of the body, and any rehabilitation programme must consider both open and closed chain activities as well as those to enhance dynamic stability (Wilk, Arrigo, \& Andrews, 1996). Walking requires the cooperation of a large number of muscles and joints (Bernhard Haas, 2005). If muscles of the upper body and trunk are in continuous contraction because of tension, the kinetic chain system is not able to work normally. Furthermore the lack of visual feedback and feedback from the inner ear additionally disturbs the kinetic chain system. All these factors result in poor balance.

Flexibility is the range of motion of a joint or group of joints. Flexibility is specific to a joint and its surrounding tissues (Morrow, Jackson, Disch, \& Mood, 2005). Previous studies have shown that flexibility of the upper body and trunk can be trained and measured successfully by different methods in normally sighted persons. In a study by King et al. (2000) 103 older adults participated in a 12-month intervention consisting of moderate-intensity endurance and strengthening exercises (Fit \& Firm) or stretching and flexibility exercises (Stretch \& Flex) for the neck, shoulders and upper body. The effect was measured using perceived physical functioning and other health-related quality of life outcomes. The stretching and flexibility exercises led to improvement in functional and well-being outcomes (King et al., 2000).

In another study (Hagberg, Harms-Ringdahl, Nisell \& Hjelm, 2000) 69 female industrial workers with non-specific neck and shoulder pain completed a 12-week intervention (38 women with isometric shoulder endurance training and 31 women with isometric shoulder strength training). The outcome was measured by assessing self-reported pain and rating of perceived exertion, arm motion performance, shoulder muscle strength and shoulder muscle endurance tests. Shoulder muscle strength exercises in addition to isometric shoulder endurance training improved results more than endurance training alone. Pain often results from a lack of flexibility of muscles and joints.

Yamauchi et al. (2005) studied the efficacy of a 12-week well-rounded exercise programme (WREP), consisting of flexibility, resistance and aerobic exercises in 23 sedentary older adults and 17 controls. Upper body functional strength was assessed using the 30second Arm Curl Test and upper body flexibility using the Back Scratch Test. By combining aerobic, resistance and flexibility exercises, WREP was effective in improving endurance, functional strength, dynamic balance and agility, and flexibility.

The sit and reach test is a universally used test of trunk flexion, although it was designed to measure the flexibility of the low back and hamstring muscles. The YMCA version of this test is described by Morrow, Allen, Jackson, Disch, \& Mood (2005).

We have found no previous study of the flexibility of the trunk in individuals with visual impairment and individuals with both visual and hearing impairments. Colak, Bamac, Aydin, Meric \& Özbeck (2004) assessed the effect of playing goalball on some measures of motor fitness. In this study one hundred and three children (aged 13-15 years) with varying degrees of low vision were assessed for range of motion of the upper extremity by standard goniometric measurement: flexion, extension, abduction, adduction and degrees of internal and external rotation of the shoulder. Significant improvement was shown in the mobility of the shoulders. 
Two studies have investigated the effect of physical exercises on dynamic balance in blind and visually impaired persons. In a study by Larsson \& Frändin (2006) dancebased training in adults aged 30-62 years improved dynamic balance. In addition, Clary, Barnes, Bemden, Knehans \& Bemden (2006) found that "Ballates" training effectively improved dynamic balance while step aerobics and walking programs improved both static and dynamic balance in sedentary females aged 50-75 years.

One aim of the present study was to investigate the effect of a 5-6-week physical training program on flexibility of upper body and trunk in visually impaired and deaf-blind persons. Another aim was to compare the flexibility of the participants in an experimental and a control group with and without previous physical activity. Good flexibility of the upper body and trunk improves balance and stability of the body (Whittle, 2007), which results in easier independent navigation from place to place. The physical training program was designed for visually impaired and deaf-blind persons to alleviate their most common physical problems: those of balance, posture, coordination, tense neck and shoulder muscles, and loss of spinal rotation and reciprocal arm swing (Surakka \& Kivelä, 2008, http://jvi.sagepub.com/). The program consisted of open and closed movements of the upper limb because the upper limb is used in both closed and open chain activities (Sparkes, 2005). The third aim was to investigate the reliability of the two tests for flexibility of upper body and trunk from the Health-Related Fitness Test battery of the UKK Institute (The President Urho Kaleva Kekkonen Institute for Health Promotion Research) for upper body and trunk (Suni at al. 1996) in visually impaired and deaf-blind persons.

\section{METHOD}

\section{Participants}

A prerequisite for participation in the study was the absence of disabilities or diseases that might prevent effective physical training and completion of the study. All participants were volunteers (clients of the Rehabilitation Services for visually impaired or deaf-blind volunteers at the Department of Ophthalmology, Helsinki University Central Hospital). The participants were recruited by asking their motivation and interest to participate in the study. They were assigned randomly to the experimental and to the control groups. Eight participants in the experimental group and six participants in the control group had a history of previous regular physical activity (30-60 minutes, 1-3 times a week) while the others did not have any history of regular physical activity (see Tables 1 and 2). In this study "blind" is defined as a person with visual acuity of less than 0.1 (counting fingers, vision to light perception) or a visual field less of than $10^{\circ}$ with glare and hemeralopia. Partially sighted means a best corrected visual acuity of less than 0.3 in the better eye. All deaf-blind participants benefited from hearing aids.

\section{Instruments}

In the context of the body, an extremity may be seen as representing an open kinetic chain if the distal end of the extremity is not in contact with a relatively stable surface. In an open kinetic chain motion at one joint does not require motion at other joints. If the distal end of the extremity is fixed, as in pull-ups or push-ups, the extremity represents a closed kinetic chain. In this closed system, movement of one joint cannot occur without causing predictable movements of the other joints in the extremity (Floyd, 2009). We selected two flexibility tests (neck and shoulder muscles and side-bending to the left and right) from the Health-Related Fitness Test Battery (HRFT) for Adults of the UKK Institute for evaluating flexibility of the upper body and trunk. These tests were selected 
because the movement chains during measurement are open. Flexibility of the neck and shoulder muscles is easiest to assess when only one shoulder joint and surrounding muscles are moving. This is possible only with open kinetic chain movement. We selected the flexibility test of the trunk for the same reason.

Table 1 Characteristics of Participants in Experimental Group

\begin{tabular}{cccccccc}
\hline Participant & Gender & Age (years) & Sight/Hearing & Weight $(\mathrm{kg})$ & Height $(\mathrm{cm})$ & Physical activity & Training \\
1 & Male & 42 & Deaf-blind & 76 & 184 & - & 14 \\
2 & Female & 46 & Deaf-blind & 53 & 155 & - & 16 \\
3 & Female & 47 & Part.sighted & 54 & 152 & B & 12 \\
4 & Male & 50 & Blind & 86 & 179 & A, C & 15 \\
5 & Male & 50 & Blind & 74 & 177 & G & 11 \\
6 & Male & 50 & Deaf-blind & 93 & 180 & A, C & 14 \\
7 & Female & 51 & Part.sighted & 83 & 162 & D & 15 \\
8 & Male & 53 & Blind & 88 & 169 & A & 14 \\
9 & Male & 54 & Part.sighted & 110 & 181 & - & 14 \\
10 & Female & 55 & Blind & 75 & 166 & - & 11 \\
11 & Female & 58 & Part.sighted & 59 & 164 & C & 14 \\
12 & Female & 62 & Part.sighted & 109 & 157 & - & 14 \\
13 & Female & 63 & Part.sighted & 94.6 & 173 & - & 14 \\
14 & Female & 69 & Part.sighted & 65 & 155 & - & 17 \\
15 & Female & 75 & Part.sighted & 64 & 153 & A & 15
\end{tabular}

Physical activity $=$ previous physical activity $\quad$ Part.sighted $=$ partially sighted $\quad$ Training $=$ number of training sessions $\mathrm{A}=$ walking, $\mathrm{B}=$ nordic walking, $\mathrm{C}=$ fitness exercises, $\mathrm{D}=$ swimming, $\mathrm{E}=$ water crawling, $\mathrm{F}=$ long walks and skiing, - = without previous physical activity

Table 2 Characteristics of Participants in Control Group

\begin{tabular}{ccccccc}
\hline Participant Gender & $\begin{array}{c}\text { Age } \\
(\text { years })\end{array}$ & Sight/Hearing & $\begin{array}{c}\text { Weight } \\
(\mathrm{kg})\end{array}$ & $\begin{array}{c}\text { Height } \\
(\mathrm{cm})\end{array}$ & $\begin{array}{c}\text { Physical } \\
\text { activity }\end{array}$ \\
1 & Female & 45 & Blind & 45 & 157 & - \\
2 & Female & 46 & Part.sighted & 67 & 168.5 & A, C, D \\
3 & Male & 48 & Blind & 83 & 178 & E, B \\
4 & Male & 50 & Blind & 103 & 182 & - \\
5 & Male & 51 & Part.sighted & 81 & 180 & - \\
6 & Male & 54 & Deaf-blind & 65 & 162 & C \\
7 & Female & 57 & Deaf-blind & 54.2 & 158 & - \\
8 & Female & 60 & Part.sighted & 53.2 & 160 & A, D \\
9 & Female & 60 & Deaf-blind & 74 & 157 & - \\
10 & Female & 63 & Blind & 79 & 165 & A \\
11 & Female & 63 & Blind & 57 & 160 & - \\
12 & Male & 65 & Deaf-blind & 76 & 163 & - \\
13 & Male & 66 & Blind & 68 & 178 & - \\
14 & Male & 67 & Deaf-blind & 82.5 & 184 & F
\end{tabular}

Physical activity $=$ previous physical activity $\quad$ Part.sighted $=$ partially sighted $\mathrm{A}=$ walking, $\mathrm{B}=$ fitness exercises, $\mathrm{C}=$ water crawling, $\mathrm{D}=$ gymnastic, $\mathrm{E}=$ judo, $\mathrm{F}=$ exercise cycle, $-=$ without previous physical activity 
Flexibility of the upper body was measured using the shoulder-neck mobility test. The flexibility of the upper body was estimated visually. In the tests the participants stand with their backs against the wall; the feet are placed at a distance of one and half foot lengths from the wall. The buttocks, back and shoulders rest against the wall. The participants are instructed to raise their hands as far as possible while keeping their upper arms close to the ears. The backs of the hands are turned towards the wall and the elbows are kept straight. The results are recorded separately for the right and left sides on the basis of the final position of the hands in relation to the wall $(0=$ severe restriction of arm range of motion (ROM), no hand contact with the wall; $1=$ moderate restriction of ROM, only the fingers reach the wall; $2=$ no restriction of ROM, the whole dorsal side of the hand is in contact with the wall (Figure 1). Flexibility of the trunk was measured by testing side-bending to the right and to the left. Two parallel lines, $15 \mathrm{~cm}$ apart, are marked on the floor immediately in front of a wall. The participants stand on the marked lines with their backs against the wall, the scapulas and buttocks resting against it. The arms are kept straight at the sides of the body.
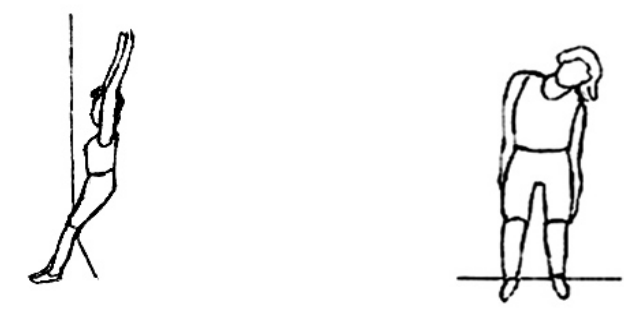

Figure 1 \& 2

Test of flexibility of the trunk

The position of the tip of the middle finger on both sides is marked with a horizontal line on the lateral thigh, first in the upright position, and then at the end point of lateral flexion. No rotation of the trunk or movement of the pelvic area is allowed, and the heels have to remain in contact with the floor. The participants are instructed to bend to the right and then to the left as far as possible while keeping their shoulder blades and buttocks in contact with the wall. The middle finger slides down along the lateral thigh. The outcome is the distance the fingertip moves down the leg during maximum lateral bending. A tape measure is used to measure the distance between the markings on the thigh in centimetres (Figure 2). Each test was performed only once because flexibility increases with each repetition. The measurement was standardized by measuring once only.

\section{Procedures}

The training programme (Surakka \& Kivelä, 2008), with special emphasis on the upper body and trunk, was designed for visually impaired and deaf-blind persons to improve their most common physical problems: balance, posture, coordination, tense neck and shoulder muscles, and loss of spinal rotation and reciprocal arm swing.

The physical interventions lasted 5-6 weeks. The participants attended 60-minute exercise sessions three times per week in three groups with supervision. The participants performed the exercises at a moderate level of intensity of between 12 and 14 on the Borg Scale (Borg, 1998). The warm-up exercises (5 min) and eight physical exercises were performed in a standing position (35 min). During the intervention, the participants performed two to three sets of 10-15 repetitions of each exercise with both legs and arms. The recommendation for home training following the intervention was to advance to 3 sets of 20 repetitions. After every set of repetitions of each exercise, the participants marched on the spot for 20 seconds with reciprocal arm swings (elbows straight to relax shoulders). Repetitions of all exercises were performed without a break. Fifty percent of the stretching exercises (15 $\mathrm{min})$ were performed in a standing position. The remaining $50 \%$ of the stretching exercises and relaxation techniques $(5 \mathrm{~min})$ were performed in the supine position on a gymnastics mat (Surakka \& Kivelä, 2008). 
The instructor, who supervised the training sessions, was specialized and experienced in orientation and mobility instruction of visually impaired and deaf-blind persons. The name of each exercise helped participants to memorize the exercise more quickly. In addition to verbal instructions with descriptive directional words the visibility of the entire physical training programme was optimized through appropriate, personalized artificial lighting conditions for each participant and through strong color contrasts between the instructor demonstrating the exercises and the wall behind her. When required, a participant could place his or her hands on the instructor's body to feel the movement. In the group consisting of visually impaired and deaf-blind volunteers, all participants exercised inside an induction loop. The instructor had one microphone fixed to her chest and the other microphone fixed to the record player. The deaf-blind participants set their hearing aids to microphone position. Thereafter they received only the speech of the instructor and the music of the record player directly into the ears without hearing surrounding sounds. Each warm-up exercise, the eight physical exercises and the stretching and relaxation trained the upper body and the trunk. The warm-up and physical exercises consisted of open chain exercises for the upper body. In the stretching phase the upper body was pushed up from the prone position to straight elbows with repetitions (a closed chain exercise).

For reliable comparison the flexibility of the upper body and trunk was measured one to two days before and after the intervention. Test and retest of the control group were performed at intervals of 2-3 days. All tests were performed at the same time of day for each participant. The same instructor made all these measurements to ensure that the measurement and visual assessment of the upper body were carried out exactly same way.

\section{Data analysis}

The 2-sided Wilcoxon signed rank test (Siegel \& Castellan, 1988) was used to compare the results of the pre- and post-tests for flexibility of the trunk and upper body in the experimental group and for comparing the test-retest results in the control group. The Wilcoxon signed rank test is very useful for comparing results before and after an intervention for the same person. The Fligner-Policello rank test or also called robust rank order test (Fligner \& Policello, 1981; Siegel \& Castellan, 1988) was used to compare the results of side-bending in the participants with and without previous physical activity in pre-testing of the experimental group and in testing of the control group. A statistical test commonly used to test a hypothesis for two independent groups is the Wilcoxon-Mann-Whitney test (Siegel \& Castellan, 1988). This test assumes, however, that both groups are sampled from the same population so that the distributions and consequently also the variances of the experimental and the control group are the same. If this restriction cannot be assumed the Wilcoxon-Mann-Whitney test is not appropriate and instead the FlignerPolicello (robust rank order test) can be used.

\section{RESULTS}

The results of the experimental group showed statistically significant improvement in the flexibility of the trunk measured as the mean of left and right side-bending for the entire group with a $p=.0068$ (Figure 3 ). In the pretests no statistically significant difference in flexibility was found between right and left side-bending in the experimental group (Wilcoxon signed ranks test $(p=.49)$ ). No statistically significant difference was found in the post-tests either $(p=.49)$. The flexibility of the trunk in the control group as measured by side-bending to the left and right was the same in test-retest; the mean of left and right side-bending was $\mathrm{p}=.33$ (Figure 4 ). 
The UKK Institute has measured the flexibility of the trunk in adults of three different age groups (31-40, 41-50 and 51-60 years). Ninety-six males and 102 females were measured in the group 41-50 years and 100 males and 97 females in the group 51-60 years. Based on these measurements the institute calculated normal values for female and male flexibility of the trunk. In the pretest of the experimental group the flexibility of ten participants was clearly worse than average and that of one participant somewhat worse than average. In the test of the control group the flexibility of six participants was clearly worse than average and that of three participants somewhat worse than average.
The results of the flexibility of the upper body of the experimental and the control group are shown in Figures 5, 6, 7 and 8. In Figures 3-8, which show that age, gender, previous physical activity and level of disability did not affect the results of pre-test, post-test or test-retest, the participants are arranged in order of increasing age.

No statistically significant difference was found between the groups with and without previous physical activity (the FlignerPolicello rank test, $p=.49$ ). The test showed no restriction of ROM in either arm in seven participants in the experimental group and in six participants in the control group. The results of the control group showed that the reliability of these two tests of HRFT is good.

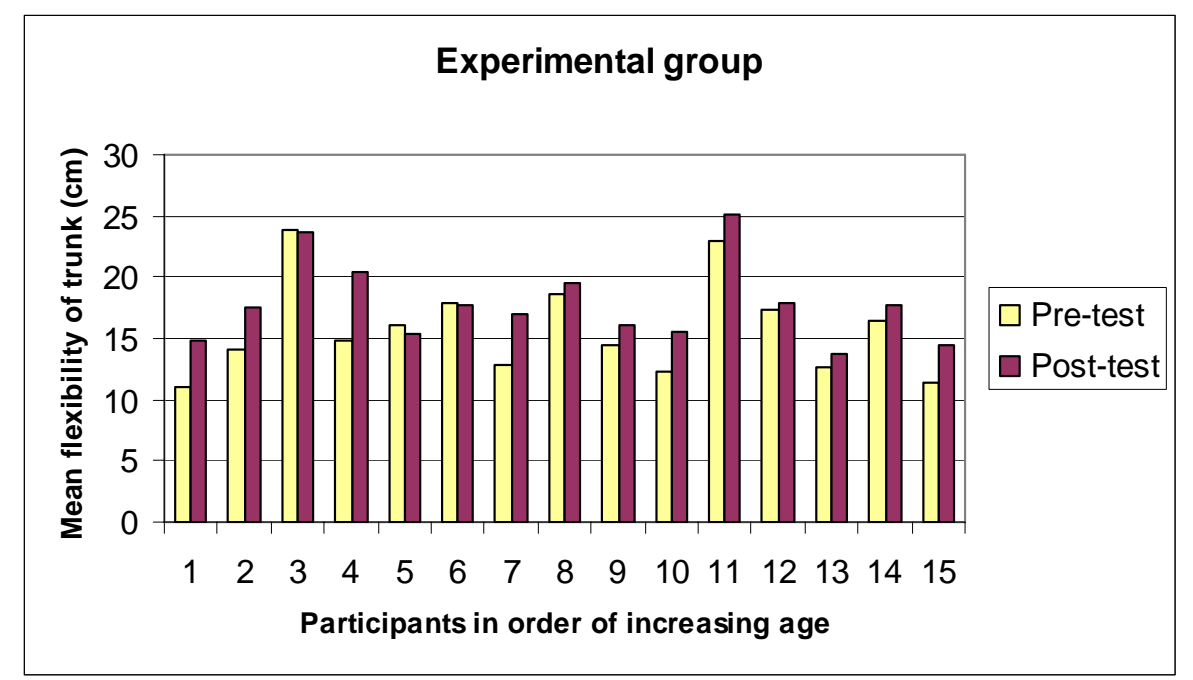

Figure 3. The results of the experimental group

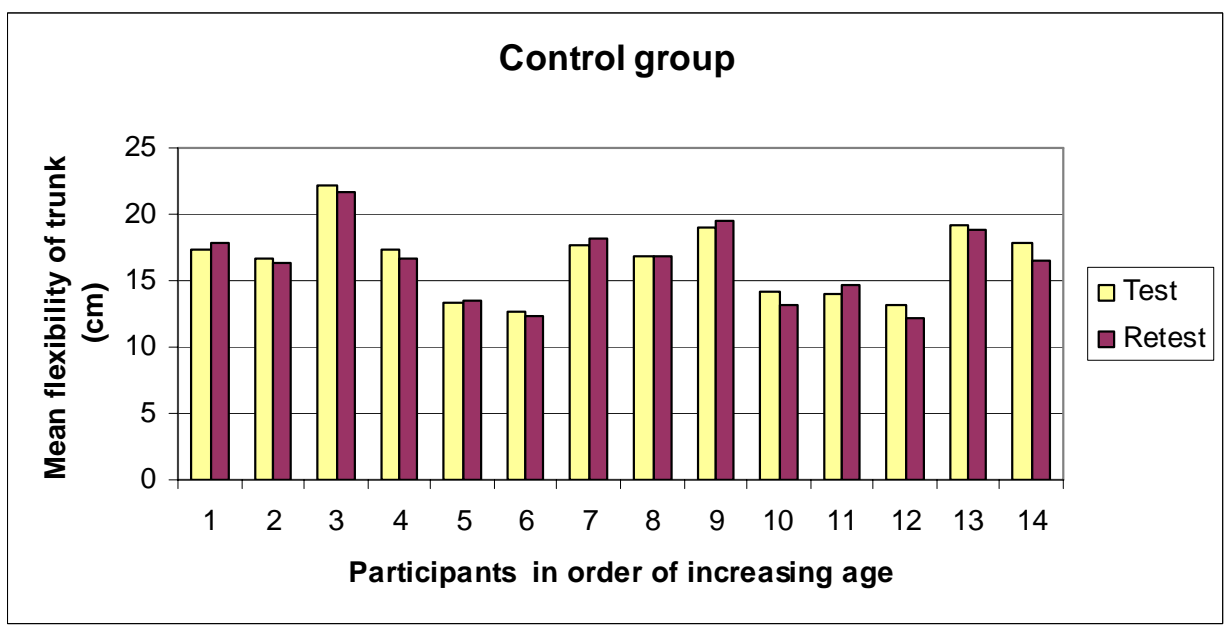

Figure 4. The flexibility of the trunk in the control group 


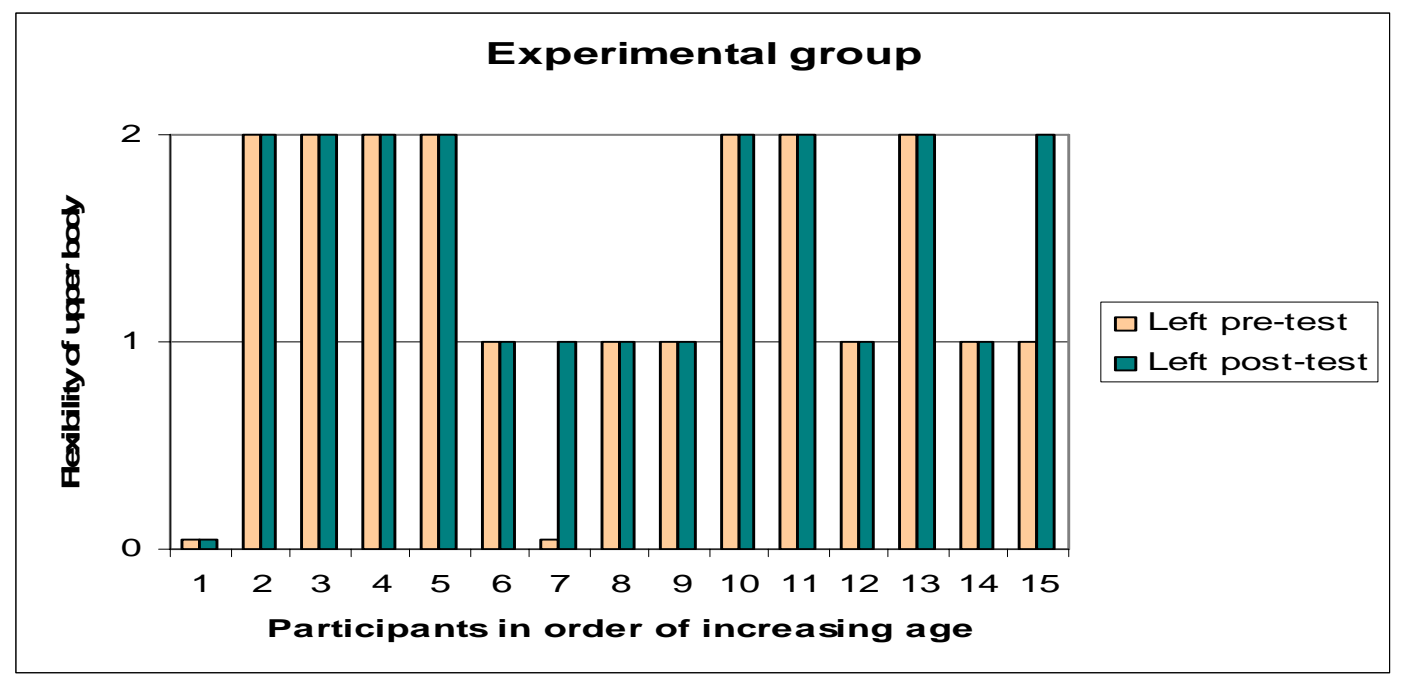

Figure 5. The classification of arm ROM: $0=$ severe restriction of range of arm ROM, no hand contact with the wall; $1=$ moderate restriction of arm ROM , only the fingers reach the wall: 2 = no restriction of arm ROM, the whole dorsal side of hand is in contact with the wall.

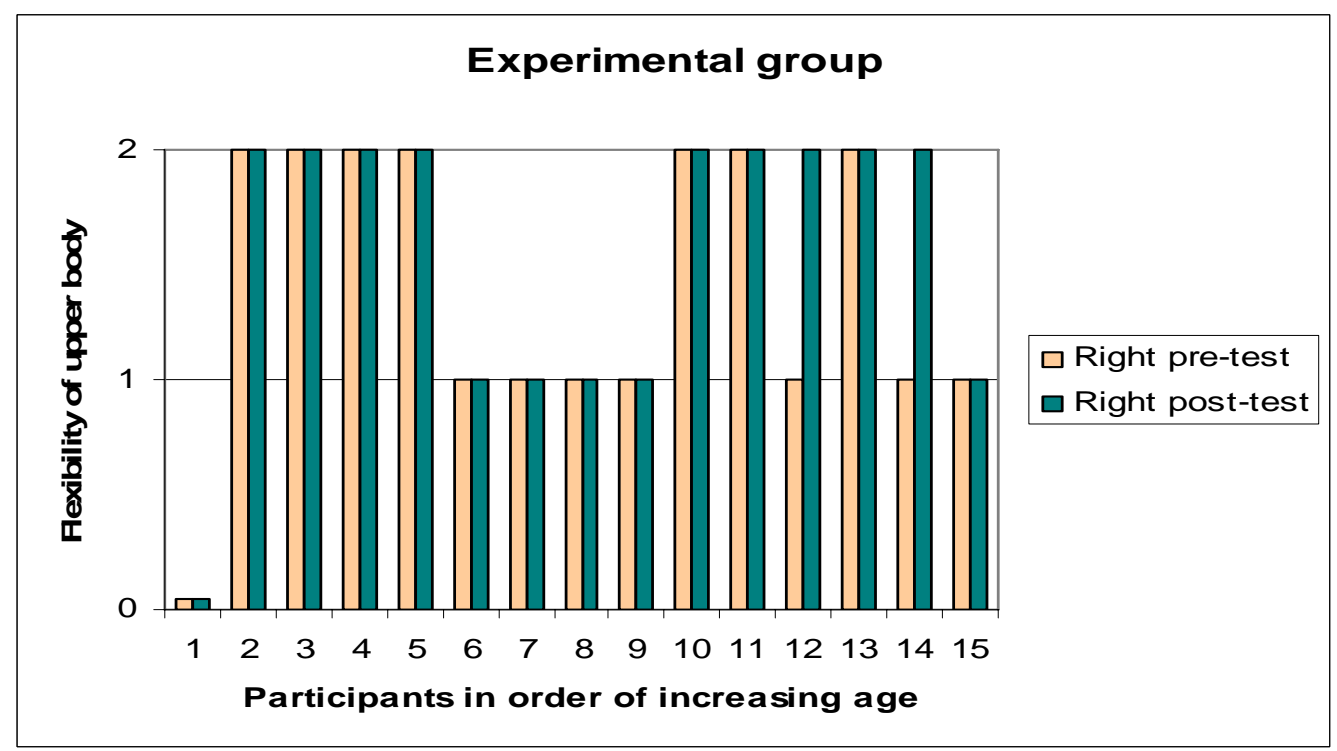

Figure 6. For the classification of arm ROM, see legend to Figure 5.

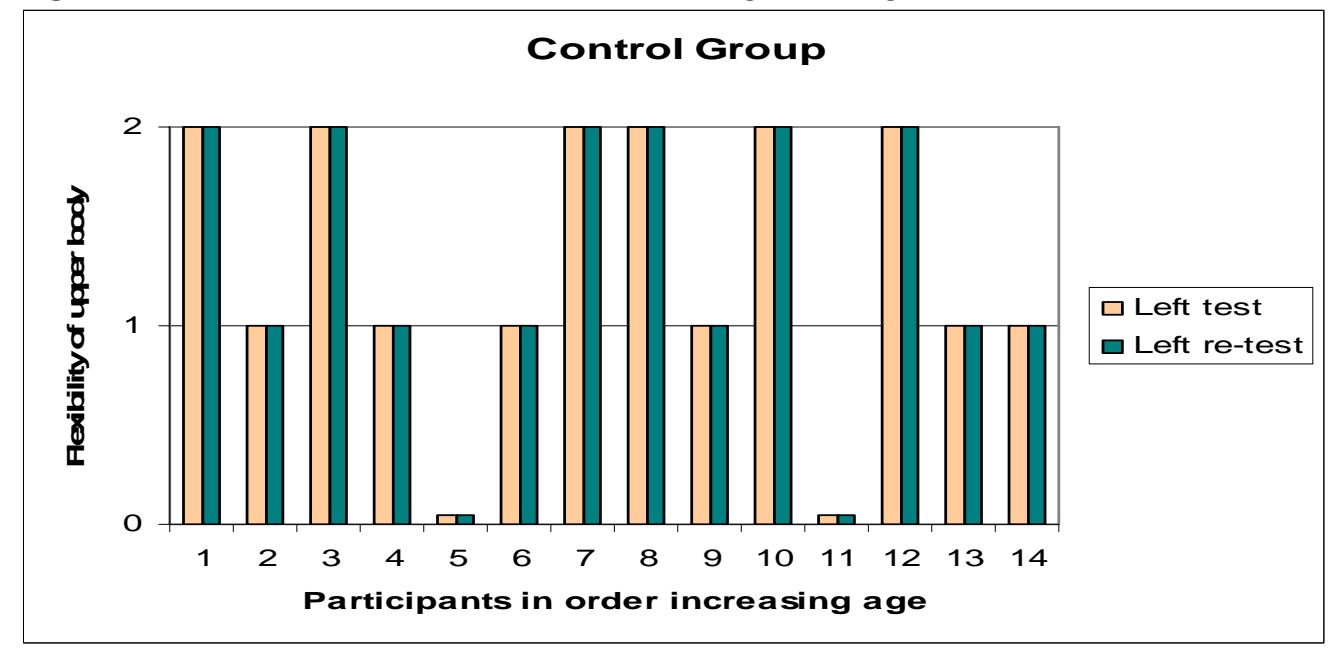

Figure 7. For the classification of arm ROM, see legend to Figure 5. 


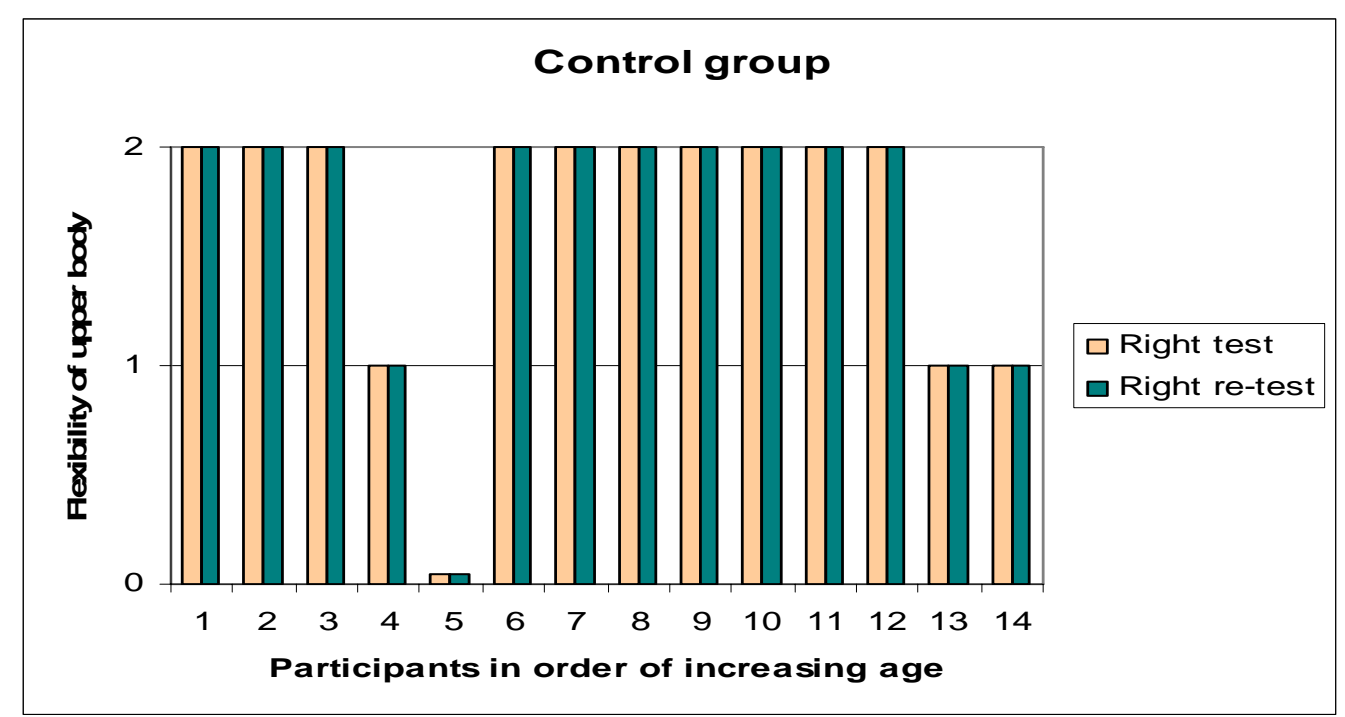

Figure 8. For the classification of arm ROM, see legend to Figure 5.

\section{DISCUSSION}

As mentioned, neck and shoulder pain and ROM can be improved with different types of physical exercises in normally sighted persons when the physical intervention lasts from 12 weeks to 12 months (King et al., 2000; Hagberg et al., 2000; Yamauchi et al., 2005). Larson \& Frändin (2006) and Clary et al. (2006) showed that various physical exercises can improve dynamic balance in visually impaired and blind persons in 8 and 13 weeks. Visually impaired and deaf-blind persons often need more time to learn physical exercises because most of them are unable to follow visual demonstration which accelerates learning. Most of them have to learn exercises only by listening to instructions. Therefore physical exercises have to be easy to learn without the possibility of being performed incorrectly, while nevertheless being challenging.

Our physical training programme is designed to be easy to continue at home. It requires little space (and is safe for visually impaired and deaf-blind persons) although the entire body is moving simultaneously in different standing positions of the body with simultaneous varying movements of the upper and lower extremities. In daily life we must be able to control our body and balance during slow and quick movements. Therefore our training programme contained repeatedly changing rhythms of various types of music (from slow to quick) with the aim of improving balance and making the exercises more enjoyable. At home visually impaired and deaf-blind persons can choose the music according to their preference. Deaf-blind persons generally have an induction loop at home (if they benefit from hearing aids) or are able to receive one if desired.

The Fligner-Policello rank test showed no statistically significant difference between the participants with and without previous physical activity in pre-testing of the experimental group and testing of the control group. One reason for this may be unbalanced types of physical activity (for example only walking) or low intensity of physical exercises. The effect of physical exercises is specific, limiting the effect to active muscles only (McArdle, Katch, \& Katch, 2007). Therefore exercises with a broad spectrum of well-designed exercises are more beneficial to balance and the entire body.

The reliability of the tests has been addressed by Suni et al. (1996), who also investigated the safety and feasibility of a health-related 
fitness test battery for adults (Suni et al. 1998). Musculoskeletal fitness tests such as shoulder-neck mobility and trunk sidebending were quick and easy to administer and these two tests were safe and feasible. We wanted to further check the reliability of these two tests among visually impaired and deaf-blind persons when the tests are carried out at the same time of day for each participant (control group - test-retest). We selected these two tests from the UKK Institute's Health-Related Fitness Battery because they are easy to carry out and do not require any special equipment. Flexibility of shoulder-neck mobility is easiest to assess when only one shoulder joint and adjacent muscles move. This is possible only with open chain movement. We selected the flexibility test for the trunk for the same reason. In contrast, in tests such as the Back Scratch Test, for example, several muscles and joints move simultaneously. Some participants were more 60 years old but we believe that these tests are suitable for them, too.

A big difference between right and left sidebending or between left and right shoulderneck mobility can explain the tendency of veering to the right or to the left, which affects independent navigation. Regarding flexibility of the upper body (shoulder-neck mobility) the results in the experimental group indicate that statistically significant improvement requires more training sessions, although some improvement was found. Flexibility of the trunk showed a statistically significant improvement in the experimental group in spite of the intervention being short, especially for visually impaired and deafblind persons. Good flexibility of the upper body and trunk is important for everyone but it is vital to visually impaired and deaf-blind persons because it makes independent navigation easier.

Our study suggests that 5-6 weeks is too short a period to achieve statistically significant results in flexibility of the upper body but long enough to achieve statistically significant improvement in flexibility of the trunk.

The duration of the physical intervention was also long enough to allow participants to develop a feeling of good mental and physical well-being, as shown by the self assessment by the participants with and without previous physical activity, including earlier interventions. According to this assessment physical condition improved in 22 participants, mental state in 21 participants and balance in 11 participants (Surakka \& Kivelä, 2008).

A limitation of the measurement of shoulderneck mobility (flexibility of the upper body) in this study is that the test uses only a 3-point scale. The score of severe restriction ( 0 ) does not describe the level of restriction exactly enough. This is illustrated by two examples from the experimental group. The right hand of participant 1 was $55 \mathrm{~cm}$ from the wall in the pre-test and $48 \mathrm{~cm}$ from the wall in the post-test. His left hand was $65 \mathrm{~cm}$ from the wall in the pre-test and $57 \mathrm{~cm}$ from the wall in the post-test. The right hand of participant 7 was $9 \mathrm{~cm}$ from the wall in the pre-test and so her pre-test result was the same as that of participant 1 although the difference between their results was marked. In cases like this standard goniometric measurement would grade the flexibility of the upper body more accurately.

In conclusion, the results showed that visually impaired and deaf-blind persons have abnormal tension and stiffness in the trunk and also in the upper body. We propose that in the future motivationally oriented, supervised interventions should last 2-3 months, with interim tests to provide exact data about any progress made. The interim data from these interventions might make it possible to plan a physical intervention of suitable length for obtaining significant alleviation of physical problems and for motivating visually impaired and deaf-blind persons to continue regular multidimensional physical exercises. 
A further study is needed to determine how long the improved upper body and trunk flexibilities persist and to establish the ideal frequency and duration of training needed to maintain the improved flexibility.

\section{Acknowledgements}

Supported by the Helsinki University Central Hospital Research Funds. The authors wish to thank Mr. Jorma Surakka, Licentiate of Technology, for the mathematical and statistical handling of the results.

\section{REFERENCES}

Borg, G. (1998). 'Borgs Perceived Exertion and Pain Scales', in G. Borg (ed.). Human Kinetics (1st ed. pp.49) Champaign, IL: Human Kinetics Publishers.

Clary, S., Barnes, C., Bemden, D., Knehans, A., \& Bemden, M. (2006). Effects of ballates, step aerobics, and walking on balance in women aged 50-75 years. Journal of Sport Science and Medicine, 5, 390-399.

Fligner, M.A., \& Policello, G.E. (1981) Robust rank procedures for the BehrensFisher problem.Journal of the American Statistical Association, 76 (373), 162-168.

Floyd, R.T. (2009. Muscular analysis of upper extremity exercises. Manual of Structural Kinesiology (17 ${ }^{\text {th }}$ ed. pp. 205-226). New York: McGraw Hill Companies Inc.

Haas, B. (2005). The neural Control of human movement. In M.Trew \& T. Everett (Eds.) Human Movement (5 $5^{\text {th }}$ ed. pp. 75-88). Edinburg: Churchill Livingstone.

Hagberg, M., Harms-Ringdahl, K., Nisell, R., \& Hjelm, E.W. (2000). Rehabilitation of neck-shoulder pain in women industrial workers: A randomized trial comparing isometric shoulder endurance training with isometric shoulder strength training. Archives of Physical Medicine and Rehabilitation, 81, 1051-1058.

Howe, T., \& Oldman, J. (2001). Posture and Balance. In M. Trew \& T. Everett (Eds.) Human Movement (4 ${ }^{\text {th }}$ ed. pp. 225-233). Edinburg: Churchill Livingstone.
Kibler,W.B. (1998). The role of scapula in athletic shoulder function. American Journal of Sports Medicine, 26, 325-337.

Kibler,W.B., McMullen,J., \& Uhi,T. (2001) Shoulder rehabilitation strategies, guidelines and practice. Orthopedic Clinics of North America, 32 (3), 527538.

King, A.C., Pruitt, L.A., Phillips, W., Oka, R., Rodenburg, A., \& Haskell, W.L. (2000). Comparative effects of two physical activity programs on measured and perceived physical functioning and other health-related quality of life outcomes in older adults. Journal of Gerontology: Medical Sciences, 55 A (2), M 74-M 83.

Larsson, L. \& Frändin, K. (2006). Body awareness and dance-based training for persons with acquired blindness - on balance and gait speed. Visual Impairment Research, 8, 25-40.

McArdle, W.D., Katch, F.I., \& Katch, V.L. (2007). Individual Differences and Measurement of Energy Capacities. In Exercise Physiology (pp.230). Baltimore: Lippincott Williams \& Wilkins.

McArdle, W.D., Katch, F.I., \& Katch, V.L. (2007). Training for Anaerobic and Aerobic Power. In Exercise Physiology (pp. 470-471).

Baltimore: Lippincott Williams \& Wilkins. Morrow, J.R., Jackson, A.W., Dish, J,G., \& Mood, D.P. (2005). Physical Fitness and Activity Assessment in Adults. In Measurement and Evaluation in Human Performance (pp. 222-273). United States: Human Kinetics.

Ray, C.T., Horvat, T., Croce, R., Mason, C., \& Wolf, S. L. (2008). The impact of vision loss on postural stability and balance strategies in individuals with profound vision loss. Gait \& Posture, 1 (28), 58-61.

Rosen,S. (1997). Kinesiology and sensorimotor function. In B.B. Blasch, W.R.Wiener \&R.L.Welsh (Eds.). Foundations of Orientation and Mobility ( $2^{\text {nd }}$ ed., pp. 170-199). New York: American Foundation for the Blind. 
Siegel, S., \& Castellan, JR. N.J. (1988). The case of one sample, two measures or paired replicates. In Nonparametric Statistics for the Behavioural Sciences ( $2^{\text {nd }}$ ed., pp. 87). Boston: McGraw-Hill.

Sparkes,V.(2005). Function of upper limb. In M.Trew \& T.Everett (Eds.), Human Movement (5 ${ }^{\text {th }}$ ed., pp.191-206). London: Elsevier.

Suni, J.H., Oja, P., Laukkanen, R.T., Miilunpalo, S.I., Pasanen, M.E., Vuori, I.M., ... Bös, K. (1996). Health-related fitness test battery for adults: Aspects of reliability. Archives of Physical Medicine and Rehabilitation, 77, 399- 405.

Suni, J.H., Oja, P., Miilunpalo, S.I., Asikainen, T-M., Laukkanen, R.T., Oja, P., Pasanen, M.E., ... Vuori, I.M. (1998). Safety and feasibility of a health- related fitness test battery for adults. Physical Therapy, 2 (78), 134-148.

Surakka, A., \& Kivelä, T. (2008). Motivating visually impaired and deaf-blind people to perform regular physical exercises. British Journal of Visual Impairment, 26, 255268.
Welsh, R.L. (1997). The psychosocial dimensions of orientation and mobility. In B. B. Blasch, W. R. Wiener \& R. L. Welsh (Eds.), Foundations of Orientation and Mobility (2nd ed., pp. 221). New York: American Foundation for the Blind.

Whittle, M.W. (2007). Normal gait. In Gait Analysis: an introduction (pp. 47-80). London: Elsevier.

Wilk, K.E., Arrigo, C.A., \& Andrews, J. R (1996). Closed and open kinetic chain exercises for the upper extremity. Journal of Sport Rehabilitation, 5(1), 88-102.

Woollacott, M., Debu, B., \& Mowatt, M. (1987). Neuromuscular control of posture in the infant and child: Is vision dominant? Journal of Motor Behaviour, 19(2), 167-186.

Yamauchi, T., Islam, M. M., Koizumi, D., Rogers, M.E., Rogers, N.L., \& Takeshima, N. (2005). Effect of homebased well-rounded exercise in community-dwelling older adults. Journal of Sports Science \& Medicine, 4, 563-571.

Corresponding author's e-mail address: airi.surakka@elisanet.fi

\section{(Abstract)}

\section{AUSWIRKUNGEN EINES KÖRPERLICHEN TRAININGSPROGRAMMS AUF DIE FLEXIBILITÄT VON OBERKÖRPER UND RUMPF BEI SEHBEHINDERTEN UND BLINDEN PERSONEN}

Optimale Rumpfdrehung, Schulterrotation und gegengleiche Armschwünge sind notwendig für gutes Gleichgewicht und sicheren Gang. Ziel dieser Studie war es, die Auswirkungen eines multidimensionalen Flexibiliträts-Trainingsprogramms für Oberkörper und Rumpf bei sehbehinderten und blinden Personen zu untersuchen. Die Teilnehmer(innen) wurden nach Zufallsprinzip der Versuchs- und der Kontrollgruppe zugeteilt. Fünfzehn Teilnehmer(innen) (12 sehbehindert und drei taub-blind, $M$ Alter 55 Jahre, SD 9.0) absolvierten das 5-6 Wochen dauernde Trainingsprogramm (drei 60 Minuten-Einheiten pro Woche). Die Kontrollgruppe bestand aus 14 Teilnehmer(innen) (neun sehbehindert und fünf taub-blind, $M$ Alter 57 Jahre, SD 7.2). Zwei Beweglichkeitstests aus der Health-Related Fitness Test-Batterie des UKK-Instituts wurden für die Überprüfung der Ergebnisse verwendet. Die Versuchsgruppe zeigte signifikante Verbesserungen in der Rumpfbeweglichkeit (Durchschnitt der Werte für die Links-Rechts-Seitbeugung, $p=.0068$ Wilcoxon-Vorzeichen-Rang-Test). Bei der Versuchsgruppe zeigte der Pre-Test uneingeschränkte Flexibilität des Oberkörpers bei sieben Teilnehmer(inne)n. Beim Post-Test zeigten vier 
Teilnehmer(innen) verbesserte Flexibilität. Der Test-Retest der Kontrollgruppe ergab gute Reliabilität dieser beiden Tests. Der Fliegner \& Policello-Test ergab keine signifikanten Unterschiede zwischen den Teilnehmer(inne)n mit und ohne regelmäßige körperliche Aktivität $(p=$ .49).

SCHLÜSSELWÖRTER: körperliches Training, Messmethoden für Beweglichkeit, Sehbehinderung, Taubblindheit

\section{(Résumé) \\ EFFET D'UN PROGRAMME D'ENTRAINEMENT SUR LA SOUPLESSE DES MEMBRES SUPERIEURS ET DU TRONC CHEZ DES PERSONNES DEFICIENTES VISUELLES ET NON VOYANTES/MALENTENDANTES}

Une rotation optimale du tronc, des épaules et un balancement réciproque des bras sont nécessaires pour la marche et un bon équilibre. Le but de cette étude était d'étudier l'effet d'un programme d'entrainement multidimensionnel sur la souplesse des membres supérieurs et du tronc chez des personnes déficientes visuelles et non voyantes/malentendantes. Les participants ont été aléatoirement assignés au groupe expérimental ou au groupe contrôle. Quinze participants (12 malvoyants et 3 non-voyants/malentendants, âge moyen 55 ans, SD 9.0) ont suivi un programme d'entrainement physique de 5-6 semaines (3 sessions de 60 minutes par semaine). Le groupe contrôle était composé de 14 participants (9 malvoyants et 5 non-voyants/malentendants, âge moyen 57 ans, SD 7.2). Deux tests de souplesse de 1' "Health-Related Fitness Test battery" de l'institut UKK ont été utilisé afin d'évaluer les résultats. Une amélioration significative de la souplesse du tronc (flexion latérale droite/gauche) pour le groupe expérimental a été démontrée ( $\mathrm{p}$ $=0.068$, Wilcoxon Rank Test). Un pré-test pour le groupe expérimental n'a démontré aucune restriction de mobilité des membres supérieurs pour sept des participants. Une analyse après entrainement a démontré pour quatre participants une amélioration de la souplesse. L'étude de répétabilité du groupe contrôle a démontré une bonne validité de ces deux tests. Le test de Fligner \& Pociello n'a démontré aucune différence significative entre les participants pratiquant régulièrement ou non une activité physique régulière $(\mathrm{p}=0.49)$

MOTS CLES : entrainement, souplesse, méthodes de mesure, déficience visuelle, nonvoyants/malentendants

\section{(Аннотацця) \\ ВЛИЯНИЕ ИСПОЛЬЗОВАНИЯ ПРОГРАММЫ ФИЗИЧЕСКОЙ ПОДГОТОВКИ НА ГИБКОСТЬ ВЕРХНЕЙ ЧАСТИ ТЕЛА И ПОЗВОНОЧНИКА У СЛАБОВИДЯЩИХ И СЛЕПОГЛУХИХ ЛИЦ}

Оптимальный изгиб туловища, вращения плеч и взаимодействующие колебания рук необходимы для хорошего равновесия и походки. Целью данного исследования стало изучение влияния физической учебной программы на гибкость верхней части тела и туловища у слабовидящих и слепоглухих людей. Участники были случайным образом распределены в экспериментальную и контрольную группы. Пятнадцать участников (12 слабовидящих и три слепоглухих, средний возраст 55 лет, SD 9.0) выполнили 5-6-недельные программы физической подготовки (три 60-минутных занятий в неделю). Контрольная группа состояла из 14 участников (девять слабовидящих и пяти слепоглухих, средний возраст 57 лет, SD 7.2). Экспериментальная группа показала статистически значимое улучшение гибкости позвоночника (в средней стороне изгиба влево и вправо, $\mathrm{p}=0,0068$ ). В 
экспериментальной группе предварительное тестирование показало, неограниченную гибкость верхней части тела у семи участников. В последующем тестировании четырех участников результаты показали более высокую гибкость. Повторное тестирование контрольной группы показало хорошую надежность этих двух тестов. Тест Fligner \& Policello не показал статистических различий между участниками с учетом регулярной физической деятельности и без $(\mathrm{p}=0,49)$.

КЛЮЧЕВЫЕ СЛОВА: физическое воспитание, нарушения зрения, глухота и слепота

\section{EFECTO DE UN PROGRAMA DE ENTRENAMIENTO FÍSICO SOBRE LA FLEXIBILIDAD DEL TREN SUPERIOR Y TRONCO EN PERSONAS CON DISCAPACIDAD VISUAL Y SORDO-CIEGOS}

Giro óptimo de tronco, rotación de hombro y del oscilaciones del brazo recíproco son necesarios para un buen equilibrio y para la marcha. El propósito de este estudio fue examinar el efecto de un programa de entrenamiento físico multidimensional en la flexibilidad de la parte superior del cuerpo y el tronco en personas con discapacidad visual y sordo-ciegos. Los participantes fueron asignados aleatoriamente en un grupo experimental y grupo control. Quince participantes (12 con discapacidad visual y 3 sordos-ciegos, con una edad media de 55 años, SD 9.0) completaron a lo largo de 5-6 semanas de duración un entrenamiento físico (tres sesiones de 60 minutos por semana). El grupo control estaba formado por 14 participantes $(9$ con discapacidad visual y 5 sordo-ciegos, con una edad media de 57 años, SD 7.2). Para evaluar los resultados se utilizaron 2 test de flexibilidad de una batería de prueba de aptitud física relacionada con la salud del Instituto UKK. El grupo experimental mostró estadísticamente una mejoría significativa en la flexibilidad del tronco (media de flexión lateral a la izquierda y la derecha, $\mathrm{p}=0,0068$ test de Wilcoxon). En el grupo experimental un pre-test demostró una flexibilidad sin limitaciones de la parte superior del cuerpo en 7 participantes. En un post-test de 4 participantes mostraron una mayor flexibilidad. El test-retest del grupo de control mostró una buena fiabilidad de estas dos pruebas. La prueba de rango Fligner y Policello no mostró ninguna diferencia estadística entre los participantes con y sin actividad física regular $(\mathrm{p}=0,49)$.

PALABRAS CLAVE: entrenamiento físico, métodos de medición de la flexibilidad, deficiencia visual, sordo-ciegos

\section{(Resumo)}

\section{EFEITO DE UM PROGRAMA DE TREINO (FÍSICO) NA FLEXIBILIDADE TREM SUPERIOR E DO TRONCO EM PESSOAS COM DEFICIÊNCIA VISUAL E COM SURDO-CEGUEIRA}

A Torção ideal do tronco, a rotação do ombro e o balanço recíproco dos braços são necessários para um bom equilíbrio e para a marcha. O objetivo deste estudo foi examinar o efeito de um programa de treino físico na flexibilidade da parte superior do corpo e do tronco em pessoas com deficiência visual e com surdo-cegueira. Os participantes foram divididos aleatoriamente para o grupo experimental e para o grupo controlo. Quinze participantes (12 com deficiência visual e 3 com surdo-cegueira, com média de idade de 55 anos, DP 9.0) completaram um programa de treino físico com a duração de 5-6 semanas (três sessões de 60 minutos por semana). O grupo controlo foi composto por 14 participantes ( 9 com deficiência visual e 5 com surdo-cegueira, média de idade 57 
anos, DP 7,2). Para avaliar os resultados foram utilizados dois testes de flexibilidade da bateria de Testes do Instituto UKK "Health-Related Fitness Test battery". O grupo experimental apresentou melhorias estatisticamente significativas na flexibilidade do tronco (média de inclinação lateral para a esquerda e para a direita, $\mathrm{p}=0,0068$ Wilcoxon signed rank). No grupo experimental um pré-teste mostrou flexibilidade irrestrita da parte superior do corpo em sete participantes. No pós-teste, quatro participantes melhoraram a flexibilidade. $\mathrm{O}$ teste-reteste do grupo controlo apresentou boa confiabilidade desses dois testes. O teste Fligner \& Policello não mostrou nenhuma diferença estatística entre os participantes com e sem atividade física regular $(p=0,49)$

PALAVRAS-CHAVE: treino físico, métodos de medição de flexibilidade, deficiência visual, surdocegueira 